\title{
Alternaria alternata induced inflammatory lung responses: a novel in vivo PK/PD model
}

\author{
Malgorzata Gil, Michael Caniga, Joseph Eckman, Robbie McLeod, Lily Moy, Alan Wilhelm, Janice Woodhouse, \\ Jie Zhang-Hoover, Milenko Cicmil
}

From 2nd Cross Company Respiratory Symposium

Horsham, UK. 6-7 September 2012

\section{Rationale}

Asthma is a heterogeneous disorder characterized by several physiologic and immunologic phenotypes. Common environmental allergens such as pollen, house dust mite and mold induce airway inflammation and exacerbate asthmatic symptoms. Traditional rodent models of asthma use multiple sensitizations and challenges with allergens such as OVA and HDM to induce asthma like responses. Alternaria alternata is a fungal allergen linked to the development of severe asthma [1]. This allergen is capable of eliciting robust immune responses in the lungs [2]. In the current study we evaluated a single intratracheal (i.t.) instillation of Alternaria to model immune responses in Brown Norway rats.

\section{Methods}

Brown Norway rats are commonly used to study allergic asthma. In this study, animals were subjected to a single i.t. challenge with gradient doses of Alternaria alternata. A temporal profile was performed following Alternaria challenge. Inflammatory cell infiltration and cytokines (IL-5, and IL-13) were assessed in bronchoalveolar lavage fluid (BALF). Pharmacological profiling was conducted using oral dosing of cotricosteriods.

\section{Results}

Alternaria induced dose and time- dependent recruitment of inflammatory cells in the lungs along with increased cytokine levels in BALF. Here we report, a time related infiltration of neutrophils in BALF. Oral dosing of corticosteroids administered prior to Alternaria instillation led to a dose-dependent attenuation of Alternaria induced airway inflammation.

* Correspondence: milenko.cicmil@merck.com

Merck Research Laboratories, Boston, MA 02115, USA

\section{Conclusions}

A single i.t. instillation of Alternaria induced significant inflammation in the lung. Preliminary profiling suggests that Alternaria challenge has the potential to be a robust and reliable PK/PD model to assess in vivo compound potency.

Published: 14 August 2013

\section{References}

1. Denning DW, O'Driscoll BR, Hogaboam CM, Bowyer P, Niven RM: The link between fungi and severe asthma: a summary of the evidence. ERJ 2006 , 27(3):615-626.

2. Doherty $T A$, Khorram N, Kotaro Sugimoto K, Sheppard D, Rosenthal P, Cho JY, Pham A, Miller M, Croft M, Broide DH: Alternaria Induces STAT6Dependent Acute Airway Eosinophilia and Epithelial FIZZ1 Expression That Promotes Airway Fibrosis and Epithelial Thickness. J Immunol 2012, 188(6):2622-9.

doi:10.1186/1476-9255-10-S1-P10

Cite this article as: Gil et al: Alternaria alternata induced inflammatory lung responses: a novel in vivo PK/PD model. Journal of Inflammation 2013 10(Suppl 1):P10.

Submit your next manuscript to BioMed Central and take full advantage of:

- Convenient online submission

- Thorough peer review

- No space constraints or color figure charges

- Immediate publication on acceptance

- Inclusion in PubMed, CAS, Scopus and Google Scholar

- Research which is freely available for redistribution

Submit your manuscript at www.biomedcentral.com/submit 